\title{
Archaeoastronomy in the Khmer Heartland
}

\author{
GIULIO MAGLI, Politecnico di Milano, Italy
}

The heartland of the Khmer empire is filled with magnificent monuments built over the course of many centuries. These monuments include the world-famous "state temples," such as Angkor Wat, and also many other temples as well as huge water reservoirs. Using data from Google Earth as well as GIS and reconstructing the ancient sky with Stellarium, we investigate the relationships of astronomy with orientation and topography in a systematic fashion, following the methods of modern Archaeoastronomy and strictly keeping at bay vague and/or esoteric proposals put forward by previous writers. As a result, a very clear pattern of cardinal orientation and alignment arises, connected with the temples' symbolism and the management of power by the Khmer kings. As a bonus, a comparison with the Angkor monuments allows us to put forward an explanation for the anomalous orientation of two unique "peripheral" state temples of Cambodia.

\section{Key words:}

Archaeoastronomy, Angkor Temples, Angkor Wat, Stellarium, Google Earth Pro.

\section{SDH Reference:}

Giulio Magli. 2017. Archaeoastronomy in the Khmer Heartland. SDH, 1, 1, Article 1 (February 2017), 17 pages. DOI : $10.14434 / \mathrm{s} d \mathrm{~h} . \mathrm{v} 1 \mathrm{i} 1.22846$

\section{INTRODUCTION}

The Khmer empire flourished between the eighth and the fourteenth centuries AD. The heartland of the empire was located in the vast Cambodian lowlands, where the kings developed monumental temple architecture as a means for the explicit representation of their power. As a consequence, a series of masterpieces — and especially the so-called "state temples," like Angkor Wat-were constructed [Jacques and Lafond 2004]. Geographically, these buildings were concentrated in the environs of today's Siem Reap, first in the area of Roulos, and then later in Angkor, some 15 kilometers to the north. There are, however, two exceptions: Koh Ker, located in northern Cambodia, 85 kilometers northeast of Angkor, and Preah Khan of Kompong Svay, 100 kilometers to the east.

The Khmer state temples are vast rectangular enclosures with a central unit and several auxiliary buildings and shrines. The aims of such architectural ensembles, whose design in many cases also included the construction of huge barays (water reservoirs), were quite complex, since they functioned as royal residences and major cult centers attesting the beliefs and religiosity of the kings. A further funerary function for the afterlife of the king, although likely, has never been proved. Until a few years ago the temples were even conceived of as "concentrated state towns," but recent research and mapping on large scale has shown the complexity of the urbanization of the whole Angkor area, casting doubt on the idea of state temples as "capital cities" [Evans and Fletcher 2015; Stark et al. 2015].

Author's address: Giulio Magli, Department of Mathematics, Politecnico di Milano, Piazza Leonardo da Vinci 32, 20133, Milan, Italy; email: giulio.magli@polimi.it

Permission to make digital or hardcopies of part or all of this work is granted without fee according to the open access policy of SDH. (C) 2017 SDH Open Access Journal 
Another important aspect highlighted by recent research is the sophistication of the hydraulic system, which led to an impressive modification of the natural environment. It was organized into three grand areas, with the major barays acting as central collectors and with flow management systems towards the south. The barays thus had both a practical and ritualistic function in being explicitly associated with the state temples and embellished with the Mebons, the island temples built inside them [Fletcher et al. 2015].

As far as the interpretation of each temple is concerned, the connection between the two Khmer religionsBuddhism and Hinduism-must be taken into account. Their relationship was sometimes exclusive and at other times syncretistic, depending on the attitude of the ruling king. Documented historical phases of Buddhism/Hinduism reveal conflict and consequent defacing of the temples' images. In any case, construction of the temples was clearly considered mandatory to demonstrate the greatness and in some sense the divinity of the king himself. The temples thus reflected concepts related to the foundation of power and to the cosmic order. Thus, it comes as no surprise that a complex religious symbolism is self-evident in all these buildings. Inspiration certainly came from Indian sacred architecture [Malville 2000; Kak 1999; Kak 2002] and, in particular, the characteristic layout of Angkor Wat and of many other temples-a "pyramid mountain" surrounded by a moat - is usually considered to correspond with the cosmology of Mount Meru and the surrounding Sea of Milk, from which ambrosia was churned by the gods and demons.

The religious symbolism associated with cosmic order is reflected in the orientations of ancient buildings worldwide [Magli 2013], and Angkor is no exception. It is indeed well known that almost all the temples, enclosures and barays are oriented cardinally. However, although this notion is widespread [Petrotchenko 2012], as far as the present author is aware, no attempt has been made to analyze it quantitatively, using the methods of modern Archaeoastronomy [Ruggles 2015; Magli 2016]. Furthermore-and curiously—the same pattern is not respected at the two complexes located outside the heartland, so that their orientations can be defined as "anomalous." This fact has been noticed in the literature, but never explained. Yet another point which has been left unexamined is the reported existence of alignments between different temples.

In spite of, or perhaps owing to, this lack of professional archaeoastronomical investigation, pseudoarchaeological interpretations of Angkor have easily found their way into the popular media. The same holds for the "astronomical numerology" of Angkor Wat, which has been made famous by a controversial book [Mannikka 1996]. The present author has many qualms about this issue, but discussing it would be beyond the scope of the present paper.

To study the archaeoastronomy of the Angkor temples, a complete database of orientations at Angkor has been constructed here using satellite imagery, and the sky over Angkor has been reconstructed using the affordances of the planetarium software Stellarium. Although database (Table 1) is presented in a chronological fashion, the reader is warned that not all the datings of the temples are firmly established in the archaeological literature. This allows us to investigate not only orientations but also the probability of intended alignments between buildings dating to different periods. By comparison with the Angkor results, the anomalous orientations of the peripheral temples can also be interpreted as representing two different breaks in the traditional pattern of orientation. 


\section{THE ORIENTATION OF THE ANGKOR MONUMENTS}

The present author has previously gathered sample data of Angkor temples with a precision magnetic compass. However, in order to present a complete analysis based on a homogeneous, reliable and complete set of data, the azimuths used in this paper (reported in Tables 1 and 2) have all been obtained with the compass tool of Google Earth Pro. The accuracy of Google Earth in areas covered by high-resolution images is usually very good [Potere 2008], and in particular — as the author has verified by personally comparing satellite data with directly acquired theodolite measures in many different countries-the error in azimuth does not exceed $\pm 1 / 2^{\circ}$. The reliability of this estimate is particularly solid in the present case because all the data have been subjected to a double-blind control. In fact, the author was kindly allowed to consult the GIS database currently being developed by the Greater Angkor Project, and in all cases the azimuth measures furnished by this database were very close to those of Google Earth; the two "virtual campaigns" have of course been done independently, that is, without mutually adjusting the way of taking measures. As far as the horizon is concerned, it is flat for almost all monuments (the case of Angkor Wat will be treated separately) and, as we shall see, the monuments by themselves actually work as artificial horizons.

The following monuments have been listed and measured:

1) State temples.

2) Barays. The barays were handled as monuments in their own right, since their size and meticulous orientation are difficult to reconcile with purely functional aims. The results of the paper support the view that they were an essential part of the building program associated with the legitimization of kingship.

3) Island temples. They were, in many cases, constructed in already existing barays, typically by successor kings.

4) The most important secondary temples, either of royal or private construction.

Except for Angkor Wat and the secondary temple of Wat Athvear constructed by the same king, the main entrance of all the temples is to the east. For each temple, a convention similar to that commonly used for Greek temples has thus been followed, viz., the azimuth is given from inside looking out. The results (Table 1, reported schematically in Fig. 1) show that there is an obvious pattern of orientation towards true east exhibited by all the data. Since the rectangular enclosures are sometimes not perfectly squared, in the table both azimuths of the east-west and of the north-south sides are reported, but the analysis is based on the azimuths of the east-west sides.

All of the 31 monuments considered lie within an interval as small as five degrees, between $85^{\circ}$ and $90^{\circ}$. It is obvious that there is no need of statistics to conclude that the orientation was intentional. A first point is, therefore, fully confirmed: these monuments were connected to ideas of cosmic order in architecture, which imposed an orientation to the cardinal points. But the data tell us more than that. Indeed, 19 monuments out of 31 are concentrated between 89 and 90 degrees, and all those temples not perfectly oriented to due east exhibit a slight deviation exclusively to the north of east; not even one exhibits a deviation, however small, to the south of east. Are these small deviations only due to errors committed by the builders in the measurement process, or are they intentional? It is clear from the monuments themselves that the Khmer architects were extremely precise. The method they used to find the cardinal directions was probably based on the sun, a feature 
chosen for both religious and practical reasons. Indeed, finding north using the stars requires either the observation of the directions of rising and setting of a bright star on a flat, level horizon (a thing quite difficult to achieve in the humid environment of Angkor) or the observation of the motion of a circumpolar star (again, very difficult due to the very low height of the north celestial pole). Furthermore, owing to precession, no "pole star" was available in Khmer times. In contrast, the traditional method of finding cardinal directions by bisecting the shadows of a gnomon on a circle — the "Indian circle"-was certainly well known to the Khmers.

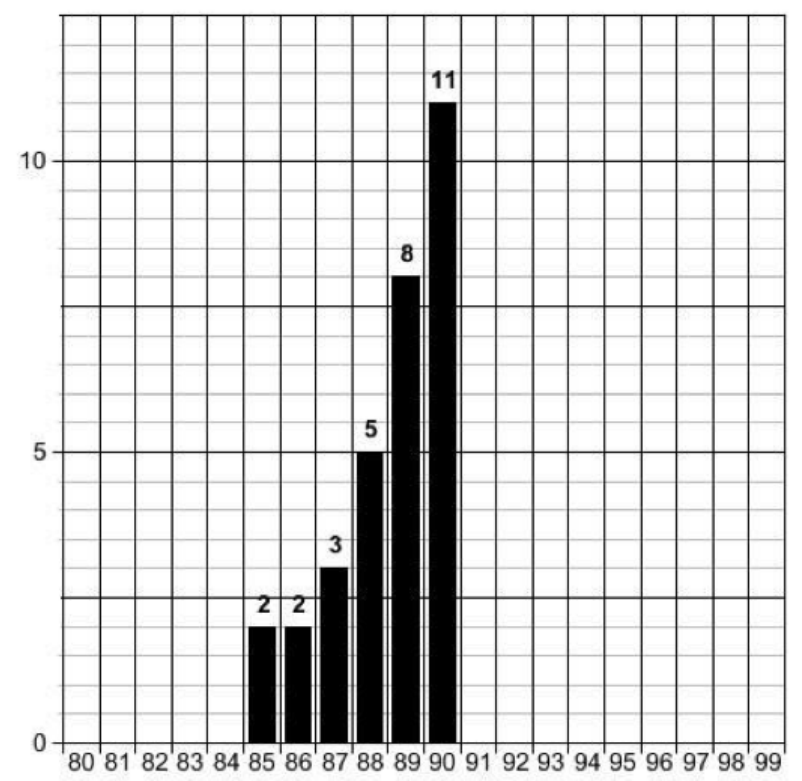

Fig. 1. Orientation histogram (azimuth in degrees vs. number of monuments) of 31 monuments of the Angkor Heartland.

Using this method, a scrupulous astronomer can easily obtain an accuracy on the order of $1 / 2^{\circ}$, if not better. We are thus led to infer that even the slight deviations observed in some temples are deliberate. In contrast, if the observed deviations had been caused by errors of measurement, then either a method which leads only to northof-east errors was devised (which is unlikely), or the results should have been distributed randomly on both sides of the expected value of $90^{\circ}$.

The key to this riddle can be found by studying the orientation of Angkor Wat, to which we now turn. The azimuth of the temple is $270.5^{\circ}$. The likely reason is that the temple was originally dedicated to Vishnu, a god closely connected to the west, as can be seen, for instance, in the upper terrace of the Bayon, whose western shrine is devoted to him. The orientation of Angkor of course implies that a person entering the enclosure from the west gate is looking along the direction of azimuth $90.5^{\circ}$. This slight deviation has an interesting consequence, which is already very well-known [Stencel et al. 1976]. Looking from the west gate towards the temple at dawn on the equinoxes, the sun is seen to rise just above the central tower, "crowning" it almost vertically. The reason is that at the latitude of Angkor the trajectory of the sun is very steep, and therefore a small increase in azimuth leads to a strong increase in height; the "horizon height" of the central tower of Angkor Wat from the western entrance is $-5^{\circ}$ and the center of the sun reaches such an altitude at an azimuth of $90^{\circ} 40^{\prime}$ 
(Fig. 2) (astronomical data in this paper are taken from Stellarium, while declinations are calculated with the program Get-Dec, kindly provided by C. Ruggles, which takes into account refraction and parallax).

So far, so good for the Angkor Wat orientation. It is now obvious, however, that if a similar phenomenon must be observed in a temple whose main access is to the east, observation will occur at sunset, and the azimuth of the temple must be slightly misaligned to the north of east. In fact, in this way the direction of the observer looking along the temple axis will point slightly to the south of west, where the equinoctial sun will be seen to disappear just above the temple.

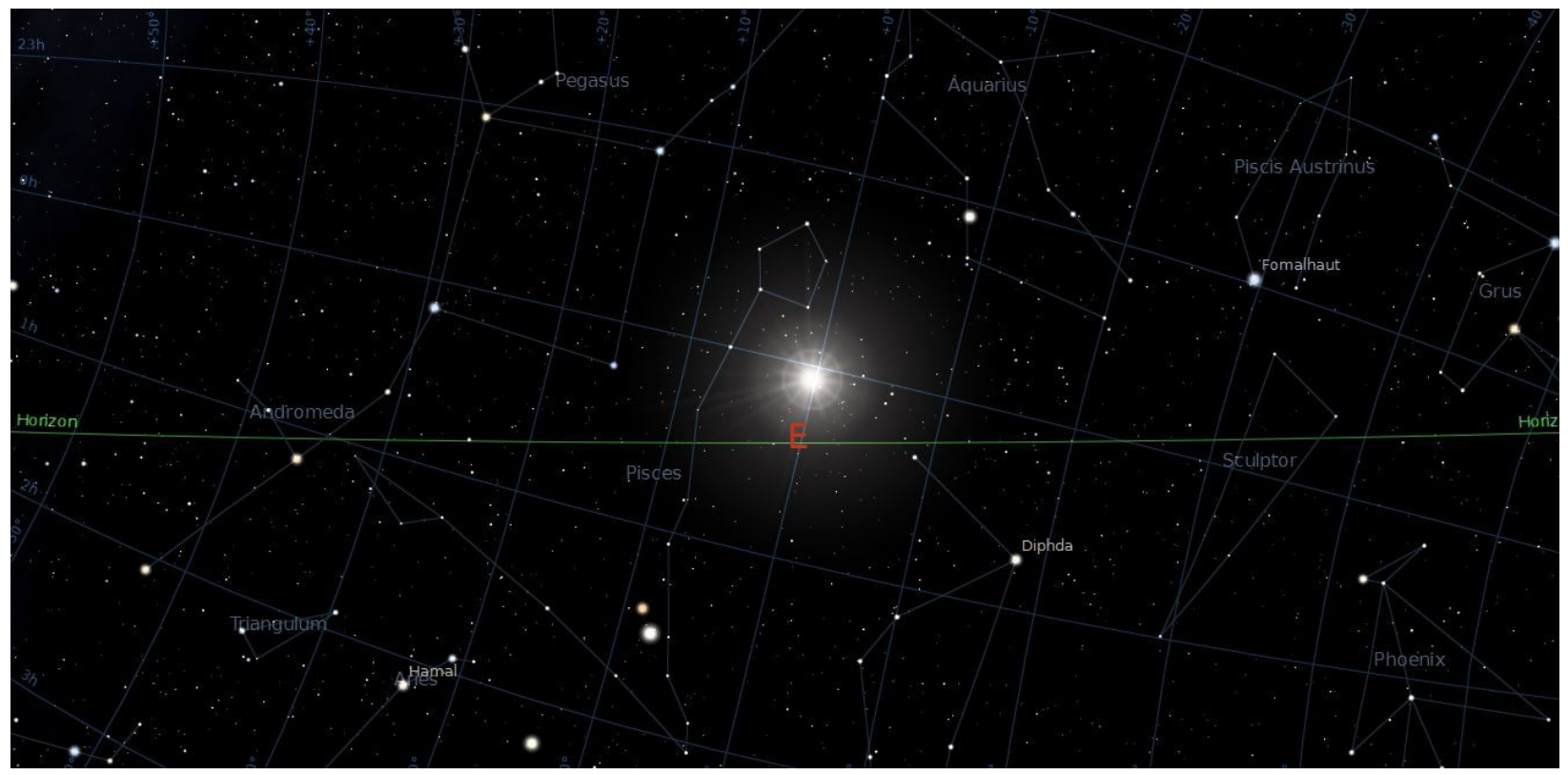

Fig. 2. Stellarium simulation of the sun rising at the Spring equinox at Angkor. The solar coordinates are: azimuth $90^{\circ} 40^{\prime}$, height $5^{\circ}$.

This is the likely explanation for the temples' orientation slightly to the north of east, and so in particular for the state temples Bakong, Phnom Bakheng and Bayon, whose azimuth ("exactly" like that of Angkor Wat, but in the opposite direction) is $89.5^{\circ}$. The phenomenon of the sun disappearing vertically behind the temple at the equinoxes in this latter case can be verified using Google Earth 3D visualization. The dimensions of the sun in Google Earth simulations are relatively big, but despite this the effect is unmistakable, as shown in Fig.3.

What is the meaning of such spectacular hierophanies? For Angkor Wat, Stencel et al. 1976 proposed a rather complex calendrical function, trying to frame the phenomenon into a series of supposed astronomical functions of the monument which, when viewed from different, suitably chosen points of the esplanade supposedly furnish, for example, the extrema of the motion of the moon at the horizon. This idea, however, is clearly biased by a strong selection effect of the observation points, and in any event there is no evidence that the Khmer monuments were used for making precise astronomical observations. The key is instead symbolic: the beautiful hierophany of the sun suspended just above the mountain temples at the equinoxes was very probably intended as a materialization of the connection of the temple itself with the heavens, since it brings about a match between the zenith in the sky and the cardinal directions on the ground. 


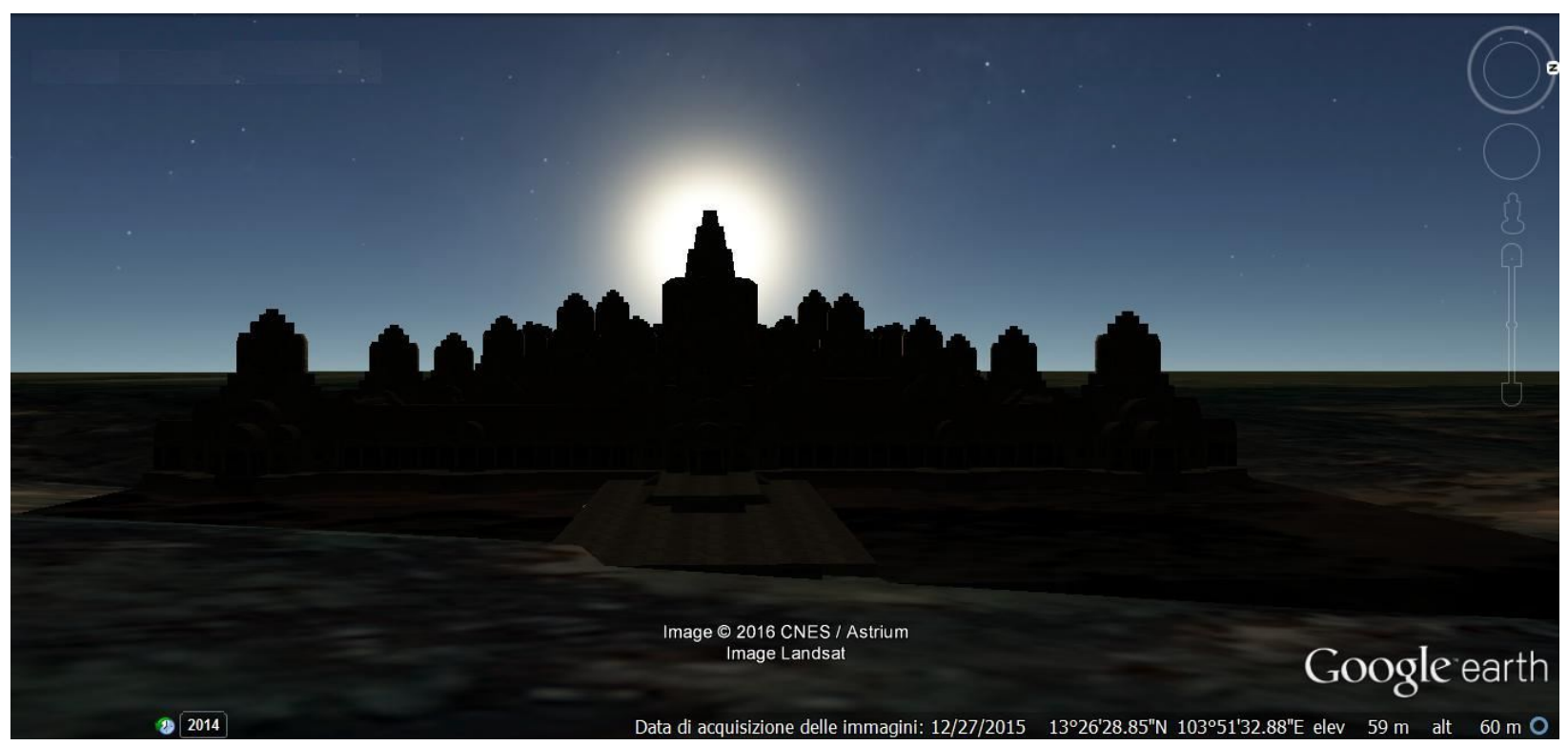

Fig. 3. Google Earth simulation of the setting of the sun behind the Bayon at the spring equinox.

The recent discovery that the zenith passages were probably also made visible inside the temples [Barnhart and Powell 2013] supports this interpretation, as well as the well-known general connection of the temple mountain architecture with the axis orthogonal to the earth's surface- the zenith-nadir axis to which, respectively, the temple and its image reflected in the waters in front of it explicitly allude. In fact, although the simplest way to observe the zenith passages is to look for the days in which the shadow of a post vanishes at noon, another effective way is to use a straight vertical tube leading from the open sky into a dark chamber. If the tube is sufficiently long and narrow, the identification of the zenith passage will be accurate and, most important of all, the effect inside the room will be spectacular. This method, which was developed for example in pre-Columbian Mesoamerica, was very likely in use also in the Angkor temples. Today, their roofs are open, but the capstones are missing. Many such stones, however, are present in the rubble near the temples, and all have a hollow tube running down their axes. The holes allowed rain to hit the holy stone lingas located at the center of many chambers, and also allowed the sun passing overhead to light the same stones in spectacular hierophanies occurring twice a year (zenith passages at Angkor occur on April 26 and August 17).

The temples of the Angkor heartland were thus anchored in the cycle of the sun in two ways: the orientation, related to the equinoxes, and the vertical openings of their chambers, related to zenith passage. Yet another way to connect a temple with the zenith passages is, of course, by orienting the building to the sun rising or setting on these days, as occurs, for instance, for the world famous post-classic Maya pyramid of Chichen Itza, Yucatan. The azimuth of the rising sun on the zenith passages at Angkor is $76^{\circ}$, so apparently no Angkor temple was oriented in this way. Interestingly enough, however, the cardinal orientation appears to be a pattern, a rule only for the sacred space of Angkor, since — as we shall see in section 4- a state temple oriented to the sun rising on the days of the zenith passages actually exists outside the heartland.

Finally, a few temples remain for which the misalignment is too elevated to be attributed to considerations of visual effects. In particular, the temple exhibiting the worse misalignment with respect to due east, Banteay 
Kdei, was probably built long after the construction of the baray which lies in front of it and has the same alignment. Thus, the original rough orientation of the baray probably influenced that of the later temple for aesthetic reasons.

\section{ASTRONOMICAL ALIGNMENTS BETWEEN MONUMENTS}

The existence of scores of alignments between different monuments of Angkor was noticed many years ago by Paris 1941, who, however, offered no explanation for them. He divided his finds into cardinal (north-south or east-west) alignments, sosticial alignments, and "non-oriented" (meaning at least 3 points aligned, but not astronomically) alignments. In total, he proposed 28 cardinal alignments, 26 sosticial alignments, and 11 other alignments. In the present paper we are interested only in astronomical alignments, and therefore just cardinal and sosticial relationships will be treated in what follows (Paris also proposed geometric relationships, e.g., temples standing at the vertexes of equilateral triangles, which will not be investigated here).

I have subjected all the proposed alignments to a check for accuracy. Here are the results:

1) A few are impossible to verify, as they refer to unnamed buildings, or ruins which are not recognizable.

2) A few others are not verified within the error permitted here, namely $1 / 2^{\circ}$.

3) All the remaining ones are "correct"; in other words, they have been verified as falling within the degree of accuracy adopted in this paper.

Among the alignments which are technically verified, the following possibilities may occur.

Alignments occurring by pure chance. These alignments arise owing to a selection effect. For example, a side of a temple complex is aligned with a corner of another complex and with the opposite side of yet another one, a connection which is far more likely to occur by chance than-say-to determine that the tops of three temples are all aligned on the same meridian. In particular, we must pay special attention when the temples are too far apart and do not allow a direct view. Indeed, because of the earth's roundness, intervisibility between sites (provided that the view is unobstructed) is severely limited. A good estimate is the following: the visibility of an object which is h meters high equals the square root of $13 \mathrm{~h}$ expressed in kilometers, so that, for instance, a person 2 meters tall sees on a flat horizon as far as ca. 5 kilometers. The summits of existing temples and/or provisional wooden structures could have been used to trace longer alignments, because when the object sighted is in itself high, the heights must be added to each other and therefore the distance to the horizon increases. However, in this case, too, lines longer than ca. 11-12 kilometers (corresponding to observation points located at heights -10 meters) must be regarded as extremely suspicious.

Alignments occurring for technical reasons. The technical problem of tracing cardinally oriented lines is not an easy task. It does not suffice to determine the cardinal directions with a suitable accuracy, but it is also necessary to maintain the same accuracy during the construction of an enormous work of engineering such as the West Baray, which is 7.8 kilometers long. As a result, the lines already surveyed can be useful for a purely practical reason; for example, the top of a temple can be used as a survey point when laying out a new project. This procedure generates "true" alignments whose explanation is, however, purely functional. 
Alignments occurring for symbolic reasons. These are possible when, for example, a certain project was connected to another through an astronomical event, or a certain king wanted to create a visual connection with the monument of a previous king. Such alignments of course fall into the specific sphere of interest of Archaeoastronomy.

\subsection{Cardinal alignments}

After careful scrutiny, only a certain number of the cardinal alignments proposed by Paris survived the test of the "selection effect." Further, claiming intentionality (according to point 3 above) is possible only if the chronology of the monuments in question is perfectly clear. For this reason, in what follows, only alignments including a well-attested chronology are reported, although I do not exclude the possible existence of a few others involving other buildings, whose chronology is not yet clear.

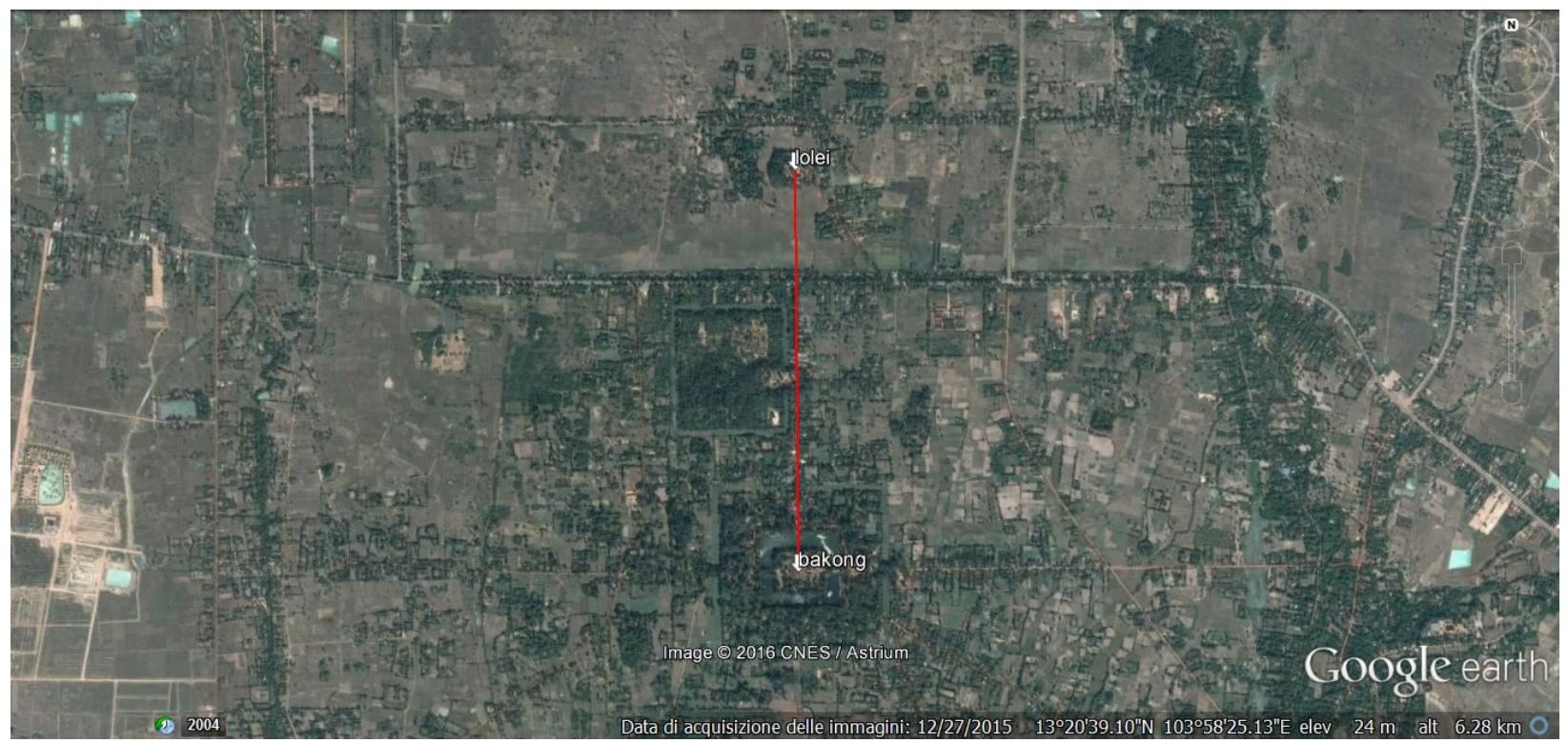

Fig. 4. The meridian line connecting Lolei with the Bakong. (Image courtesy Google Earth; drawings by the author.)

Our starting point is the first state temple built in Angkor-Roulos, the Bakong, built by Indravarman I. The temple was built along with a huge baray, the so-called Indrataka, which was located in such a way that the central axis lies on the same meridian (azimuth $180^{\circ}$ ) as the Bakong, located 1.8 kilometers to the south of the baray's center. Inside the already existing baray, Yasovarman I, (successor of Indravarman I) built the Lolei, an island temple, which was placed along the very same meridian (Fig. 4). In this way, a clearly intentional and symbolic alignment was created. The same king also "delimited" the sacred space of the future Angkor by building two temples (Phnom Krom and Phnom Bok) on the two small hills which overlook the area from the south and from the east respectively.

Around the beginning of the tenth century AD, Yasovarman I probably also initiated the construction of an even bigger baray, the East Baray, which, about 50 years later, was used by Rajendravarman II to create a symbolic configuration quite similar to that of the Lolei-Bakong. Indeed, he built his own state temple, Pre Rup, on the same meridian as the center of the East Baray, and about 1.3 kilometers to the south. Moreover, 
he added an island temple (the East Mebon) inside the already existing baray. The position chosen for the East Mebon is on the "same" meridian as Pre Rup. The reason for the quotation marks is that the azimuth of this alignment is slightly off-center $\left(178^{\circ}\right)$, but this is coherent with the orientation of Pre Rup, which indeed is $88^{\circ}$. In other words, it is clear that East Mebon was intentionally placed along the direction orthogonal to the north side of Pre Rup. Interestingly, a very long line (about 7 kilometers) almost lying on the parallel (azimuth $269^{\circ}$ ) connects East Mebon with Phimeneakeas, whose original dating is not known, but which functioned as the state temple of the successor, Suryavarman I. The Victory Gate of Angkor Thom lies along the very same direction and its placement was almost certainly chosen for the very same reason (Fig. 5).

Finally, an interesting combination of alignments also repeats for the largest of the barays, the West Baray. Here the north side is on the same parallel as the state temple of its builder, the Baphuon, which lies at a distance of 2.2 kilometers from the corner, to the east. The prolongation of the south side to the east also lies on the same parallel (azimuth $89.5^{\circ}$ ) of a temple, the pre-existing Bat Chum, at some 7.6 kilometers from the south-east corner. Finally, at the center of the West Baray, the island temple West Mebon was constructed by Udayadityavarman II (it is not completely clear if the project of the baray was already initiated by his predecessor Suryavarman I). The West Mebon is connected with Pre Rup, since a "parallel" line (azimuth 89.5 ) connects the two monuments (later, Ta Prohm was also to be built on this line). This line is very long (9.6 kilometers), but Pre Rup is 12 meters high. Clearly, since the Mebon is at the center of the baray, it is the baray itself that was planned by taking into account three reference points corresponding to the parallels of the sides and the mid line (Fig. 5).

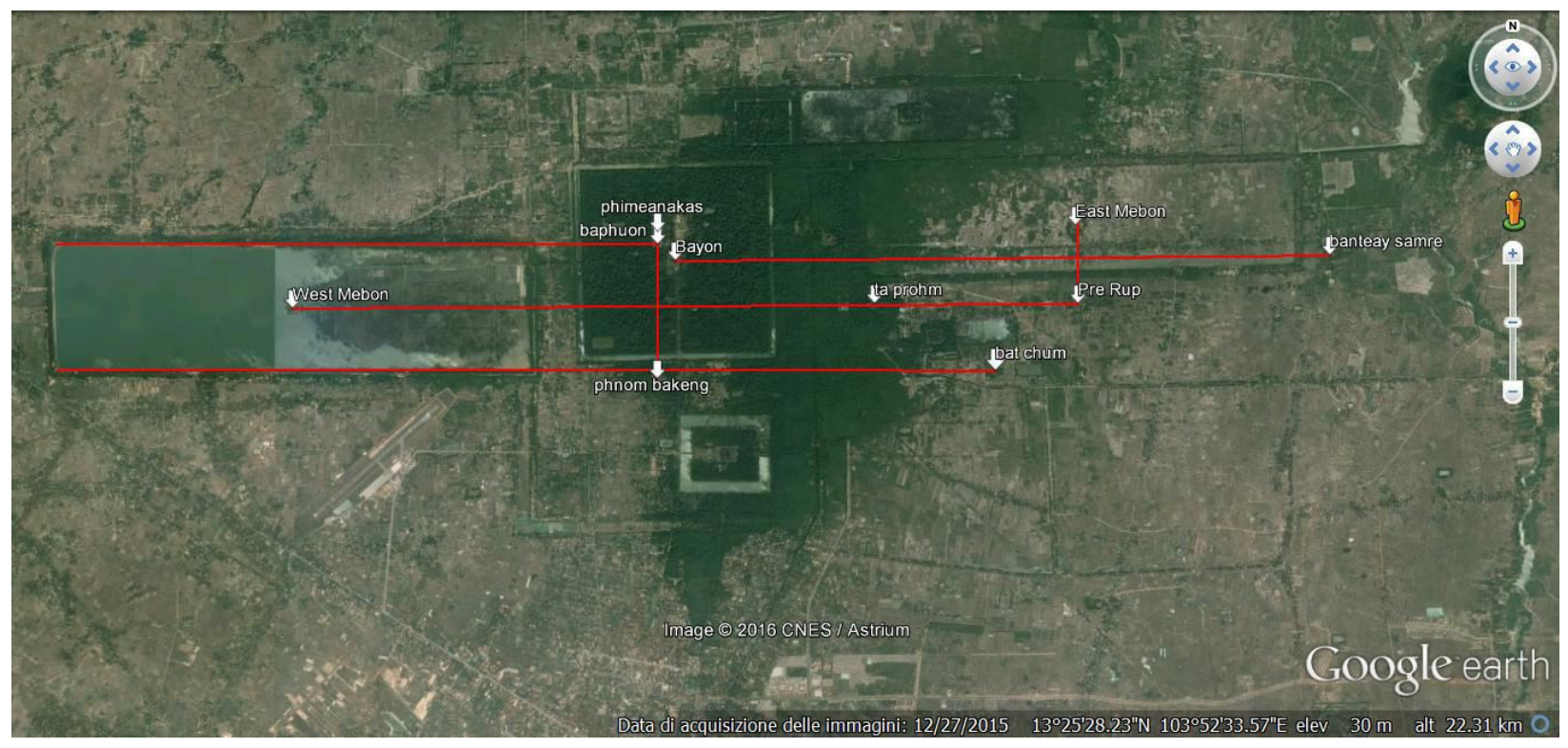

Fig. 5. Cardinally oriented alignments between main monuments at Angkor. Image courtesy Google Earth; drawings by the author.)

The reasons for the construction of the barays (whether they were functional, or ritualistic, or both) is a complex issue of Khmer archaeology as a whole and certainly cannot be addressed by the present author. I would only note here that the existence of the above-mentioned alignments, which are certainly intentional, reinforces the 
presence of a ritual function, since it was the Khmer kings themselves who drew attention to these alignments by the construction of the island temples. Building such monuments was certainly no easy task. It is difficult to believe that these islands were rapidly assembled during the dry season (and it is unclear to what extent the barays were dry during this season), and it is even more difficult to believe that they were built within the water, so the barays must have been intentionally left in a dry state (by closing the inlet moats) for a suitable time. An exception is Neak Pean, a Mebon probably built together with the baray of the Preah Khan temple.

Their construction, therefore, certainly resulted from the direct order of the kings and was motivated by symbolic reasons. The existence of the above-described topographical relationships of the barays with the state temple of their builders allowed construction of the Mebons in accordance with existing lines of sight oriented cardinally. The idea of constructing the island temples appears therefore to implement in a quite spectacular and sophisticated way a dynastic continuity which the kings wanted to make explicit (Figs. 4,5). Creating interconnecting, visual relationships with monuments built by predecessors is a means of stating the continuity of power and the "divine" rights of rulership, according to a mechanism of development of the topography of the sacred space which is similar to those found in completely unrelated cultures [Aveni and Hartung 1988] for the Mayas or [Magli 2010] for Old Kingdom Egypt. The existing alignments between barays and temples were easily compatible with this aim.

From the point of view of "dynastic" cardinal alignments, there exist two other cases which appear to be noncasual. These are:

- A very precise (azimuth $89.5^{\circ}$ ) east-west line which connects the top of the Bayon with that of the preexisting temple Banteay Samrè. The axis runs along the "Gate of the Deaths" of Angkor Thom. It is very long (about 10.8 kilometers, as it crosses the whole of the East Baray) but the top of Banteay Samrè could be used as a survey point (Fig.4).

- A perfect (azimuth $180^{\circ}$ ) north-south line which connects the axis Phimeneakeas-Baphuon with the already existing Bakheng, located outside Angkor Thom at 2.5 kilometers (Fig. 4). The latter is built on a hilltop and there is little, if any, doubt that this alignment is intentional and therefore governed the longitudinal positioning of the Phimeanakas-Baphuon complex.

In both cases, it remains to be determined if these alignments were mere survey lines or, as seems likely, there were dynastic or other traditional reasons which motivated the kings to ask that these connections be incorporated into their state projects.

\subsection{Solsticial alignments}

At the latitude of Angkor $\left(13^{\circ} 26^{\prime} \mathrm{N}\right)$ the rising azimuths of the sun at the solstices are $65.5^{\circ} / 114.5^{\circ}$. As mentioned in [Paris 1941], the existence of as many as 26 solsticial alignments between monuments is claimed. Of these, two refer to the western entrance of Angkor Wat and will be discussed separately. I have subjected all the others to an accurate verification. A few refer to monuments which are not recognizable. My conclusion on all the others is that they are likely to be random. Indeed, most alignments refer to secondary monuments and to features which can easily arise from a selection of data. For instance, consider the (very precise indeed!) "solsticial alignment" which connects the northwest corner of the enclosure of Angkor Wat with the northeast corner of the east baray. Clearly such an alignment cannot have any symbolic significance, nor can we imagine an observer who uses these two corners for solar observation. Additionally, the alignment would have no 
practical utility for a surveyor and can therefore be definitively discarded. In practice, the only case of a solsticial alignment which survives this analysis is an alignment connecting the top of Phimeneakeas with the center of Neak Pean, built later. I cannot exclude intentionality, however, from Neak Pean-restricted only to the main monuments, without considering corners and other features but only the tops-one could trace at least some 20 other "alignments" with pre-existing temples.

Regarding Angkor Wat, Stencel, Gifford and Moron [Stencel et al. 1976] produced evidence of two supposed solsticial alignments previously found by Paris [Paris 1941]. For this reason, the notion that Angkor Wat was a sort of calendrical device became widespread. According to this theory, standing at the west gate (the same position from which the equinoctial hierophany can be seen), the sun at summer solstice rises in alignment with the temple located on the Phnom Bok hill some $17.5 \mathrm{~km}$ to the northeast, while at the winter solstice it rises in alignment with a temple called Kuk Bangro, about $5.5 \mathrm{~km}$ to the southeast.

Kuk Bangro is a small and damaged ruin which is almost invisible in satellite images, and I have doubts that the alignment was ever explicitly verified after Paris found it. Indeed, today the temple is—and in all probability has always been-invisible from Angkor Wat. Furthermore, its date of construction is not known, and so it could be later than Angkor Wat. Unless a strict historical connection can be made between the two, the alignment is therefore very likely accidental.

Phnom Bok is a hill about 220 meters high, not particularly prominent from Angkor Wat. The temple on its summit had long existed when Angkor Wat was being planned, but, although the alignment is indeed verified, to attribute intentionality to it one would have to assume that the entire siting of Angkor Wat as a whole was largely governed by a desire to create this alignment, something for which there is no cultural basis whatsoever.

To summarize, the present analysis does not confirm the idea that any of the temples, Angkor Wat included, were used as "calendars in stone." In addition, there is no other evidence showing an interest for the extreme positions of the sun at the horizon by the builders of the Angkor monuments. In contrast, in view of the latitude and the climate of Angkor, their interest was rather focused on the equinoxes and the zenith passages, which were associated with the main climatic events, the transitions between the dry and wet seasons.

\section{THE ORIENTATION OF THE TWO “PERIPHERAL” STATE TEMPLES}

Two state temples were founded outside the Angkor heartland. The first, Koh Ker, was built by king Jayavarman IV in the mid tenth century AD. The site is characterized by a huge baray and by a 36-meter tall stepped pyramid, which is located on axis with the main temple, the Prasat Thom. The entire project exhibits a peculiar orientation at azimuth $76^{\circ}$ (flat horizon), which is also shared by the short sides of the baray. Sometimes topographical reasons - such as the slight south-north slope of the terrain-have been advanced for this orientation [Uchida et al. 2014], but it is difficult to believe that the architects of such a huge and complex project might have let this fact alone cause them to rotate the whole design by $14^{\circ}$.

If we search for an astronomical interpretation, an answer is readily found. At the latitude of Koh Ker, azimuth $76^{\circ}$ with flat horizon yields a declination of $+13^{\circ} 26^{\prime}$. The latitude of the site is $13^{\circ} 44^{\prime}$ so the main axis is quite precisely oriented to the rising sun on the days of the zenith passages, which of course occur when the sun has a declination equal to the latitude of the site. Therefore, when it was decided to change the site of the state temple, a change of orientation was also devised, creating for the first time an explicit connection of the axis with the sun rising on the days of the zenith passages (Fig. 6). 


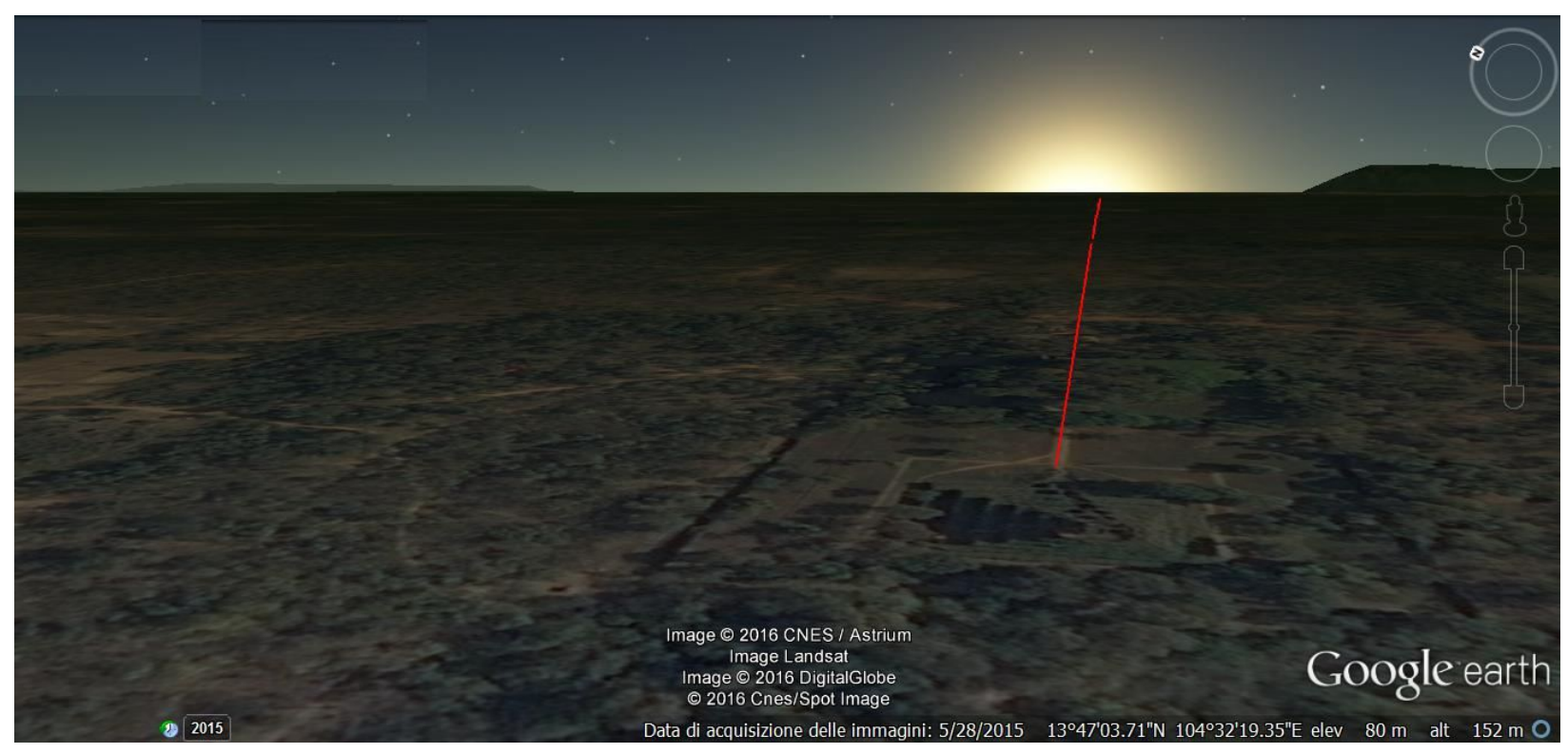

Fig. 6. Google Earth simulation of the sun rising in alignment with Kok Ker on the day of the first zenith passage. (Image courtesy Google Earth, drawings by the author.)

Even more clearly, orientation seems to have been a means of expressing a breakthrough when Preah Khan of Kompong Svay was constructed. It is a huge complex: the exterior perimeter of about $5 \mathrm{~km}$ per side makes it the largest Khmer enclosure ever built [Mauger 1939]. The site was connected to Angkor by a "royal" road rich in stone structures, such as bridges and "rest house" temples [Hendrickson 2010]. The building chronology is difficult to establish, since only one dated inscription (AD 1010) has been recovered. Accordingly, the site might have been founded in the eleventh century by king Suryavarman I. However, important architectural details point to the first half of the twelfth, during which Angkor Wat was also constructed. Curiously, other details recall the late twelfth to early thirteenth century, pointing to king Jayavarman VII, the builder of the Bayon. The religious dedication of the complex is equally difficult to identify owing to the interplay between Buddhist and Hindu elements.

The reasons leading to the construction of such a majestic architecture in such a remote place are still subject to debate. Since activities related to iron smelting were carried out in this area, it might have been an administrative center. However, the presence of such an impressive, symbolic monument is difficult to explain, and a complete re-analysis of the archaeological setting together with a new mapping of the area is currently giving new insights into this problem [Hendrickson and Evans 2015]. As far as we are concerned, there is an aspect which has been noticed by all authors but never satisfactorily explained, namely the orientation which is anomalous if compared to the Angkor monuments. The complex is indeed clearly rotated to the north of east; Mauger gives $27^{\circ} 24^{\prime}$ north of east, but repeated measures on satellite images rather point to $29^{\circ}$ north of east (azimuth $61^{\circ}$ ). It is this value which will be used here. The horizon is flat or nearly flat.

The hypothesis which has been proposed by some authors [Paris 1941] is that the complex might have been oriented to the rising sun at the summer solstice. However, the azimuth of the midsummer sun with a flat horizon in this region is $24^{\circ} 30^{\prime}$ north of east and therefore definitely far from the observed one (the variation 
of the obliquity of the ecliptic since AD 1100 is negligible, being about $\left.6^{\prime}\right)$. Of course, this does not necessarily mean that the temple was deliberately oriented to another astronomical phenomenon, but topographical reasons are difficult to imagine, and invoking "chance" is equally unsatisfactory, especially when taking into account the strict astronomical pattern which was the rule in Angkor's heartland. Furthermore, a very clear astronomical solution does exist, involving the moon. As is well known, the plane containing the earth and the moon's orbit is not the ecliptic, but forms with it an angle of $5^{\circ} 9^{\prime}$. This has the consequence that the maximal and minimal declinations which the moon can attain are greater/lesser than those of the sun (which of course equal \pm the obliquity of the ecliptic, $23^{\circ} 30^{\prime}$ ) by such an amount. This means that the moon at the horizon can attain azimuths lesser/greater than those of the sun at the solstices. Owing to a series of physical reasons, the extreme declinations (also called maximal standstills) are encountered only once every 18.6 years. Of particular interest is the full moon closest in time to the winter solstice, since it always attains a declination close to the maximal one in the year of the standstill, culminating very high in the sky and remaining in the sky almost the whole night.

Preah Khan of Kompong Svay is definitely oriented to the moon rising at the maximal northern standstill. Indeed, azimuth $61^{\circ}$ with a flat horizon at this latitude yields a declination $+28^{\circ}$. The true lunar declination at the site is actually slightly greater, $28^{\circ} 14^{\prime}$, because parallax must be taken into account. This value must be compared with the standstill declination of $+28^{\circ} 39^{\prime}$ and again, as is the case of Koh Ker for the zenith passages, the match is impressive.

Of course, the role of the moon is quite relevant both in Hinduism-where it is identified with the God Chandra — and in Buddhism, since festivals and recurrences associated with Buddha's life are timed by the full moon. The choice of orientation to the extrema of the moon might thus have arisen from this and/or from other specific messages the builder wanted to associate with the temple. To be sure, further archaeological/historical research is needed to clarify this point. There is, however, a second issue related to astronomy which is worth discussing about Preah Khan of Kompong Svay. It is known that the temple is located on the same latitude as Angkor Wat. The accuracy of this coincidence is astonishing: the center of Angkor Wat is within $1^{\prime}$ at the same latitude $\left(13^{\circ} 24^{\prime}\right)$ of the entrance to the inner enclosure of Preah Khan. The linear distance between Angkor Wat and Preah Khan of Kompong Svay is about $100 \mathrm{~km}$, and therefore no visual connection is conceivable, and it is certainly possible to think that the connection occurs by chance. Indeed, to proceed along a "straight" line between non-intervisible positions is a thing which generally makes no sense at all since there are no straight lines on a curved surface (as pseudo-archaeologists in search of "leylines" usually forget). However, the special case of sites placed at the same latitude does make sense, because-although the parallel circle is not the shortest path between two points at the same latitude-the parallel in itself is, in principle, easy to determine using astronomy, and the Khmer architects certainly possessed the necessary skills. It is indeed possible to establish latitude by measuring the height of the celestial pole or the height of the sun at midday on fixed days, and this second method was clearly favored in the present case. Ancient people interested in the zenith passages of the sun appear to have also been interested in developing precise measures of latitude, as shown, for instance, by the archaeological site of Altavista in Central Mexico. However, even admitting intentionality, obtaining the accuracy exhibited by the Angkor-Preah Khan alignment must have been quite a daunting task, which clearly demands a sound historical explanation and a symbolic, rather than functional, interpretation for the site in connection with Angkor Wat. 


\section{DISCUSSION}

The Angkor temples are masterpieces, built by knowledgeable architects who planned and erected them by taking into account a complex symbolical framework connected with the explicit representation of the ruler's power and of his relationships with the gods. The results of the present paper show that this framework included the sky, reflecting a world view in which the cycle of the sun and that of the dry and the wet seasons were tightly connected. Interest was mainly focused on the equinoxes and on the zenith passages, since both phenomena were implemented in the temples' architectural features and designs. In a few cases the temples by themselves were not isolated units but were ideally linked with pre-existing monuments, constructing a series of visually recognizable dynastic lines, which are particularly evident in the case of the Mebons, the island temples. It is thus the hope of the present author that the research presented here can contribute to clarifying historical aspects of Khmer architecture and of the king's succession. In contrast, the same results show that claims about the existence of scores of inter-connecting, almost esoteric lines between the Angkor monuments must be viewed with caution, if not skepticism.

\section{ACKNOWLEDGEMENTS}

The author gratefully acknowledges Dr. Damian Evans and the Greater Angkor Project for their kind permission to double-check the author's data with the GIS database they are developing.

\section{REFERENCES}

Anthony F. Aveni and Horst Hartung. 1988. Archaeoastronomy and Dynastic History at Tikal. In Anthony F. Aveni, ed. New Directions in American Archaeoastronomy. Oxford: BAR International Series 454, 1-11.

Edwin Barnhart and Christopher Powell. 2013. The Importance of Zenith Passage at Angkor, Cambodia. (2013). Retrieved January 20, 2017 from http://mayaexploration.com/pdf/angkorzenithpassage.pdf

Damian Evans and Roland Fletcher. 2015. The Landscape of Angkor Wat Redefined. Antiquity 89, 348 (2015), 14021419. DOI:http://dx.doi.org/10.15184/aqy.2015.157

Roland Fletcher, Damian Evans, Christophe Pottier, and Chhay Rachna. 2015. Angkor Wat: an introduction. Antiquity 89, 348 (2015), 1388-1401. DOI:http://dx.doi.org/10.15184/aqy.2015.178

Mitch Hendrickson. 2010. Historic Routes to Angkor: Development of the Khmer Road System (ninth to thirteenth centuries AD) in Mainland Southeast Asia. Antiquity 84, $324 \quad$ (2010), 480-496. DOI:http://dx.doi.org/10.1017/S0003598X00066722

Mitch Hendrickson and Damian Evans. 2015. Reimagining the City of Fire and Iron: A Landscape Archaeology of the Angkor-Period Industrial Complex of Preah Khan of Kompong Svay, Cambodia (ca. 9th to 13th centuries A.D.). J. F. Archaeol. 40, 6 (November 2015), 644-664. DOI:http://dx.doi.org/10.1080/00934690.2015.1105034

Claude Jacques and Philippe Lafond. 2004. L'Empire Khmer. Cités et sanctuaires Vth-XIIIth siècles, Paris: Fayard.

Subhash Kak. 1999. The Solar Numbers in Angkor Wat. Indian J. Hist. Sci. 34 (November 1999), 117-126.

Subhash Kak. 2002. Time, Space, and Astronomy in Angkor Wat. (2002). Retrieved January 20,2017 from http://www.ece.lsu.edu/kak/ang3.pdf

Giulio Magli. 2016. Archaeoastronomy: Introduction to the Science of Stars and Stones, Cham, ZG, Switzerland: Springer International Publishing.

Giulio Magli. 2013. Architecture, Astronomy and Sacred Landscape in Ancient Egypt, New York, NY, USA: Cambridge University Press.

Giulio Magli. 2010. Topography, Astronomy and Dynastic History in the Alignments of the Pyramid Fields of the Old Kingdom. Mediterr. Archaeol. Archaeom. 10, 2 (March 2010), 59-74. 
John McKim Malville. 2000. The Cosmic Geometries of Vijayanagara. In John McKim Malville \& Lalit M. Gujral, eds. Ancient Cities, Sacred Skies: Cosmic Geometries and City Planning in Ancient India. New Delhi: Indira Gandhi National Center for the Arts and Aryan Books International, 100-118.

Eleanor Mannikka. 1996. Angkor Wat: Time, Space, and Kingship, Honolulu, HI, USA: University of Hawaii Press.

Henri Mauger. 1939. Práh Khẵn de Kốmpon Svày. Bull. Ec. Fr. Extr. Orient. (1939), 197-220. DOI:http://dx.doi.org/10.3406/befeo.1939.3722

Pierre Paris. 1941. V. L'importance rituelle du Nord-Est et ses applications en Indochine. Bull. Ec. Fr. Extr. Orient. (1941), 303-334.

Michel Petrotchenko. 2012. Focusing on the Angkor Temples: The Guidebook 2nd ed., Michel Petrotchenko.

David Potere. 2008. Horizontal Positional Accuracy of Google Earth's High-Resolution Imagery Archive. Sensors 8,12 (2008), 7973-7981. DOI:http://dx.doi.org/10.3390/s8127973

Clive L.N. Ruggles ed. 2015. Handbook of Archaeoastronomy and Ethnoastronomy, New York, NY, USA: Springer-Verlag.

Miriam T. Stark, Damian Evans, Chhay Rachna, Heng Piphal, and Alison Carter. 2015. Residential Patterning at Angkor Wat. Antiquity 89, 348 (2015), 1439-1455. DOI:http://dx.doi.org/10.15184/aqy.2015.159

Robert Stencel, Fred Gifford, and Eleanor Morón. 1976. Astronomy and Cosmology at Angkor Wat. Science 193,4250 (July 1976), 281-7. DOI:http://dx.doi.org/10.1126/science.193.4250.281

Etsuo Uchida, Kojiro Tsuda, and Ichita Shimoda. 2014. Construction Sequence of the Koh Ker Monuments in Cambodia Deduced from the Chemical Composition and Magnetic Susceptibility of its Laterites. Herit. Sci. 2, 1 (2014), 10. DOI:http://dx.doi.org/10.1186/2050-7445-2-10

Received September 2016; revised November 2016; accepted January 2017. 


\section{APPENDIX}

Table I. Main monuments of the Angkor area

\begin{tabular}{|c|c|c|c|}
\hline & Orientation & Notes & King/date \\
\hline Preah Ko & 90180 & & Indravarman I 880 \\
\hline Bakong & 89179 & State temple & Indravarman I 881 \\
\hline Baray Indratataka & 90179 & & Indravarman I \\
\hline Lolei & 90180 & Island temple & Yasovarman I 893 \\
\hline Phnom Bakheng & 89.5179 & State temple & Yasovarman I 907 \\
\hline Baray East & 88178 & & Yasovarman I \\
\hline Phnom Krom & 90180 & & Yasovarman I \\
\hline Phnom Bok & 90179 & & Yasovarman I \\
\hline Prasat Bei & 90180 & & Yasovarman I \\
\hline Baksei Chamkrong & 90180 & & Harshavarman \\
\hline Prasat Kravan & 90179 & & Harshavarman I 921 \\
\hline East Mebon & 86177 & Island temple & Rajendravarman II 953 \\
\hline Pre Rup & 88.5179 & & Rajendravarman II 961 \\
\hline Bat Chum & 90180 & & Rajendravarman II \\
\hline Banteay Srey & 90180 & Private construction & Rajendravarman Ii 967 \\
\hline Phimeneakeas & 89179 & Date and king unsure & Rajendravarman II \\
\hline Ta Keo & 89180 & & Jayavarman V 1000 \\
\hline Chau Srei Vibol (Wat Trak) & 89.5179 .5 & $\begin{array}{l}\text { Date and king unsure; difficult } \\
\text { to measure }\end{array}$ & Suryavarman I 1000-1050 \\
\hline Baray West & 90180 & & Suryavarman I \\
\hline Baphuon & 89179 & & Udayadityavarman II 1050-1066 \\
\hline West Mebon & 90180 & Island temple & Udayadityavarman II 1050-1066 \\
\hline Angkor Wat & 270.5180 & State temple; faces west & Suryavarman II 1113-1145 \\
\hline Banteay Samre & 85175 & & Suryavarman II 1113-1145 \\
\hline Wat Athvear & 270180 & Faces west & Suryavarman II 1113-1145 \\
\hline Thommanon & Not measured & & Suryavarman II 1113-1145 \\
\hline Chau Say Tevoda & Not measured & & Suryavarman II 1113-1145 \\
\hline Beng Melea & 89.5179 & & Suryavarman II 1113-1145 \\
\hline Ta Prohm & 87.5177 .5 & & Jayavarman VII 1181-1218 \\
\hline Preah Khan & 89179 & & Jayavarman VII 1113-1145 \\
\hline Baray Preah Khan & 89178 & & Jayavarman VII 1113-1145 \\
\hline Neak Pean & 88.5178 .5 & Island temple & Jayavarman VII 1113-1145 \\
\hline Bayon & 89.5179 & & Jayavarman VII 1113- 1145 \\
\hline Banteay Kdei & 85175 & & Jayavarman VII 1113-1145 \\
\hline Baray Banteay Kdei & 86176 & & Jayavarman VII 1113-1145 \\
\hline Ta Som & 88178 & & Jayavarman VII 1113-1145 \\
\hline Krol Ko & 87177 & & Jayavarman VII 1113-1145 \\
\hline Banteay Prei & 88178 & & Jayavarman VII 1113-1145 \\
\hline
\end{tabular}


Table II. State temples outside the Angkor heartland

\begin{tabular}{|l|l|l|l|}
\cline { 2 - 4 } \multicolumn{1}{c|}{} & \multicolumn{1}{c|}{ Orientation } & Notes & \multicolumn{1}{c|}{ King/date } \\
\hline Preah Kahn of Compong Svay & 60150 & & \\
\hline Kok Ker & 76164 & & \\
\hline Baray & 76165 & & Jayavarman VII 1113-1145 \\
\hline Banteay chhmar & 88178 & & \\
\hline Baray & 88178 & & \\
\hline
\end{tabular}

